Abstracta Iranica Iranica

Revue bibliographique pour le domaine irano-aryen

Volume 42-43 | 2021

Comptes rendus des publications de 2019-2020

\title{
Maria Conterno, Marianna Mazzola (eds.). Intercultural Exchange in Late Antique Historiography
}

Florence Jullien

\section{OpenEdition}

1 Journals

\section{Édition électronique}

URL : https://journals.openedition.org/abstractairanica/54207

DOI : 10.4000/abstractairanica.54207

ISSN : 1961-960X

Éditeur :

CNRS (UMR 7528 Mondes iraniens et indiens), Éditions de l'IFRI

Référence électronique

Florence Jullien, « Maria Conterno, Marianna Mazzola (eds.). Intercultural Exchange in Late Antique Historiography », Abstracta Iranica [En ligne], Volume 42-43 | 2021, document 34, mis en ligne le 30 décembre 2021, consulté le 13 décembre 2022. URL : http://journals.openedition.org/ abstractairanica/54207 ; DOI : https://doi.org/10.4000/abstractairanica.54207

Ce document a été généré automatiquement le 13 décembre 2022.

Tous droits réservés 


\section{Maria Conterno, Marianna Mazzola (eds.). Intercultural Exchange in Late Antique Historiography}

Florence Jullien

\section{RÉFÉRENCE}

Maria Conterno, Marianna Mazzola (eds.). Intercultural Exchange in Late Antique Historiography. Louvain: Peeters, 2020, XXII-168 p. ISBN: 9789042939752, (Orientalia Lovaniensia Analecta 288)

1 Cet ouvrage est l'un des fruits du programme ERC Memory of Empire: the Post-Imperial Historiography of Late Antiquity (MEPIHLA) conduit par Peter van Nuffelen à l'Université de Gand entre 2012 et 2017, centré sur la production historiographique de l'Antiquité tardive. Les éditrices abordent le thème sous l'angle des échanges interculturels à travers les données de l'historiographie. Si l'un des objectifs initiaux de cette étude était de circonscrire le champ chronologique à l'Antiquité tardive, le cadre temporel a cependant été élargi et s'étend du IVe au XIe s. Les textes historiographiques de cette large période témoignent, comme en écho, des contacts de leurs auteurs avec d'autres cultures, par-delà les frontières : ils en conservent souvent les données linguistiques, traditionnelles ou religieuses. De telles influences s'expriment le plus souvent par des traductions ou des adaptations de sources importées d'autres aires culturelles.

Six contributions sont réunies dans ce volume, qui présentent autant de cas d'espèce limités au pourtour méditerranéen et à l'Asie occidentale :

3 H. Inglebert, "Intercultural Exchanges in Greek and Latin Histories and Chronicles" (p. 1-28) ;

4 S. Robbe, C. Noce, "Translating Eusebius' "Church History" in the West and in the East: Rufinus and his Contemporary Syriac Colleague" (p. 29-64); 
5 A. Camplani, "Transmitting and Being Transmitted. The Spread and Reception of the History of the Episcopate of Alexandria in Carthage and Aksum" (p. 65-94);

6 S. Rapp, "Caucasian Historical Literature, the Iranian Epic, and the Diversity of Late Antiquity" (p. 95-118). L'A. souligne avec justesse l'orientation trop "occidentalisante" des chercheurs dans l'approche des sources sur les premières communautés chrétiennes caucasiennes, ancrées dans "une mer romano-byzantine». Une telle approche a engendré d'importantes distorsions, notamment pour l'histoire de l'Asie occidentale et de ces mêmes communautés dont les sociétés étaient principalement enracinées dans le monde iranien, spécialement aux abords de la mer Caspienne ;

7 A. Hilkens, “ "A Wise Indian Astronomer Called Gandoubarios”: Malalas and the Legend of Yoniton" (p. 119-142);

8 M. Conterno, "Found in Translation: Agapius, the Septuagint, and the "Falsified" Torah of the Jews" (p. 143-168).

\section{AUTEURS}

FLORENCE JULLIEN

CNRS, CeRMI, Paris 